\title{
PJJ: DIGITAL TRANSFORMASI DARING PADA EVALUASI PENDIDIKAN DI ERA PANDEMI COVID -19
}

\author{
Yessy Astriani \\ astriani.yessy@gmail.com \\ (Mahasiswa Magister PAI Program Pascasarjana, Universitas Muhammadiyah Tangerang) \\ Ismail Marzuki \\ ismailmarzuki@umt.ac.id \\ (Fakultas Agama Islam Universitas Muhammadiyah Tangerang)
}

\begin{abstract}
Abstrak
Kebijakan yang dikeluarkan pemerintah terkait pandemi Covid-19, guru dan siswa harus siap menggunakan media teknologi untuk melanjutkan proses pembelajaran. Masyarakat harus lebih pintar dalam memanfaatkan teknologi digital. Dunia digital sebagai media pembelajaran seperti internet dalam e-learning merupakan media alternatif yang paling dasar dalam pembelajaran online. Pelaksanaan Penilaian Akhir Tahun (PAT) untuk kenaikan kelas di tengah wabah Covid-19 harus mengedepankan prinsip fleksibilitas, keadilan, non diskriminasi, dan tidak merugikan siswa. Semua kegiatan pembelajaran dilakukan dengan menggunakan berbagai macam media, seperti video, audio, WA/sms, Google Classrom, Google Meet, dan Google Form. Ujian sekolah dapat dilaksanakan dalam bentuk rapor nilai dan prestasi yang diperoleh sebelumnya, tugas, tes online, dan / atau bentuk penilaian jarak jauh lainnya.
\end{abstract}

\section{Kata kunci: Covid -19, Online, Evaluation Educational}

\begin{abstract}
The policies issued by the government regarding the Covid-19 pandemic, teachers and students must be ready to use technological media to continue the learning process. People must be smarter in utilizing digital technology. The digital world as a learning medium such as the internet in e-learning is the most basic alternative media in online learning. Implementation of the End of Year Assessment for class promotion in the midst of the Covid19 outbreak must prioritize the principles of flexibility, fairness, non-discrimination, and not harming students. All learning activities are carried out using various media, such as video, audio, WA / sms, Google Classrom, Google Meet, and Google Form. School exams can be carried out in the form of grades and achievements previously obtained, assignments, online tests, and / or other forms of remote assessment.
\end{abstract}

\section{Keywords: Covid -19, Online, Evaluation Educational}

\section{A. Pendahuluan}

Dunia telah dikagetkan dengan mewabahnya suatu penyakit yang disebabkan oleh sebuah virus bernama Covid-19 (Corone Virus Diseases-19). Virus yang mulai mewabah sejak 31 Desember di Kota Wuhan, saat ini telah meruntuhkan dunia dalam berbagai aspek, menyebar diseluruh penjuru dunia sehingga pada tanggal 11 Maret 2020, WHO (World Health Organization) mengumumkan hal ini sebagai pandemi global. Ratusan ribu manusia terpapar oleh covid -19 bahkan sampai menelan puluhan 
ribu korban meninggal dunia. Penularan yang sangat cepat dan sulitnya mendeteksi virus ini dikarena masa inkubasi virus ini kurang lebih dua minggu atau empat belas hari. Sehingga menjadi penyebab banyaknya korban yang berjatuhan.

Sampai saat ini dunia medis masih belum bisa menemukan obat penawar sehingga rumah sakit dan para medis merasa sangat kesulitan sehingga para korban belum dapat ditangani dengan baik. Namun dengan demikian kita harus tetap waspada dan memohon perlindungan kepada Allah SWT. Perlu kita sadari bahwa musibah covid-19 ini adalah pintu masuknya hikmah Allah SWT. Setiap ujian yang datang memberikan pelajaran dan pengalaman serta kekuatan diri. Allah selalu punya cara untuk menguji hamba hamba yang beriman. Sebagaimana Allah telah menghendaki segala sesuatu di dunia ini dengan kekuasaan Nya agar manusia berfikir.

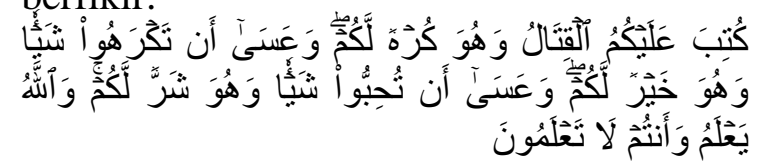

Diwajibkan atas kamu berperang, padahal berperang itu adalah sesuatu yang kamu benci. Boleh jadi kamu membenci sesuatu, padahal ia amat baik bagimu, dan boleh jadi (pula) kamu menyukai sesuatu, padahal ia amat buruk bagimu; Allah mengetahui, sedang kamu tidak mengetahui" (Al-Baqoroh: 216).

Sesuatu yang kita anggap buruk terkadang itulah yang terbaik disisi Allah dan sesuatu yang baik bisa jadi itulah yang terburuk disisi Allah. Tetaplah untuk memohon segala sesuatu kepada Robb-Mu. Maha kuasa atas segala yang ada di dunia ini. Dunia pendidikanpun merasakan dampak tersendiri dalam kebijakan yang dibuat oleh pemerintah akibat pandemi global ini. Keputusan mendadak yang dibuat oleh pemerintah kota dan daerah dengan meliburkan atau memindahkan proses belajar mengajar di sekolah menjadi di rumah membuat kepayahan pada banyak pihak khususnya para orang tua. Pelaksanaan belajar jarak jauh atau daring membuat faktor utama kekacauan pada dunia pendidikan, Walaupun pada akhirnya pemerintah memberikan solusi terhadap penilaian siswa sebagai syarat kenaikan kelas dan juga kelulusan pada semua instansi pada kondisi dan situasi emergency seperti ini. Segala upaya dilakukan demi sebuah pendidikan. Karna sejatinya ilmu akan terus kita butuhkan. ilmu itu lebih baik dari pada harta. Ilmu menjaga engkau dan engkau menjaga harta, Ilmu itu penghukum dan harta itu terhukum harta itu berkurang apabila dibelanjakan dan ilmu akan bertambah ${ }^{1}$. Ilmu harus menjadi kebutuhan primer untuk kita semua sampai ke liang lahat. Bersabda Nabi SAW:'Barang siapa yang menempuh jalan untuk mencari suatu ilmu. Niscaya Allah memudahkannya ke jalan menuju surga". (HR. Turmudzi)

Sudah menjadi tugas pemerintah dan kita tentunya untuk mewujudkan pendidikan yang maksimal meskipun saat ini banyak kendala dalam mencapai tujuan pendidikan yang diharapkan. Dengan kondisi yang seperti ini kita semua dituntut untuk bekerja ekstra demi berlangsungnya pendidikan yang terbaik untuk anak bangsa. Sejak dikeluarkannya himbauan dan peraturan daerah tentang pembatasan aktivitas sosial (social distancing) sebagai langkah antisipasi penyebaran. Covid-19 yang lebih luas pada awal bulan Maret 2020, banyak perguruan tinggi dan sekolah-sekolah yang menghentikan kegiatan belajar mengajar tatap muka di kelas. Aktivitas belajar mengajar digantikan dengan kuliah online berupa pemberian materi belajar, forum diskusi, tugas, video conference, kuis dan ujian secara online menggunakan Learning Management System (LMS) dan aplikas seperti moodle, zoom,

${ }^{1}$ Al-Ghazali, "ihya' Al-Ghazali” (jakarta :faizan, 1989) hlm.52, diterjemahkan oleh Prof. Tk. H. Ismail yakub MA-SH. 
google meet, google class, google form, jitsi, WA, telegram dan lain-lain.

\section{B. Metode Penelitian}

Penelitian ini menggunakan metode library research, digital observation, dan interviuw. Metode library research merupakan metode penelitian kualitatif sedangkan metode digital observation dan interviuw merupakan metode penelitian kuantitatif. Keduanya menggunakan data konkrit di tengah pandemi Covid-19.

\section{Pembahasan}

1. Dampak Pandemi Covid-19 pada Pendidikan Nasional

Proses pembelajaran di sekolah merupakan alat kebijakan publik terbaik sebagai upaya peningkatan pengetahuan dan skill ${ }^{2}$. Meski banyak orang tua yang merasa kesulitan terhadap kebijakan yang dikeluarkan oleh pemerintah, namun mau tidak mau kita semua harus menerima dengan lapang dada. Setelah kebijakan yang dikeluarkan oleh pemerintah terkait pandemi covid-19, guru dan siswa harus siap menggunakan media. Karna media merupakan alat yang menyampaikan atau mengantarkan pesan pesan pembelajaran. ${ }^{3}$

Termasuk dalam dunia pendidikan, secara langsung mereka para guru senior dan anak-anak usia dini yang masih sangat awam mengenai dunia teknologi, harus siap menggunakan berbagai media digital di masa pandemi covid-19. Transfer ilmu yang selama ini kita tahu dengan menggunakan daily eye contact, serta memiliki unsur rasa dan karakter antara guru dan siswa sudah tidak bisa kita

${ }^{2}$ Caroline Hodges Persell, 1979, Educations and Inequality, The Roots and Results of Strattification in America's Schools, United States of America: The Free Press.

${ }^{3}$ Azhar Arsyad, Media Pembelajaran ( JAKARTA : PT. Raja Grafindo Persada, 2008 ) hal. 3 aplikasikan lagi di tengah pandemi covid 19.

Dunia digital sebagai media pembelajaran seperti internet dalam $e$ learning adalah media alternatif yang paling pokok dalam pembelajaran online. Pemanfaatan internet menjadi alat bantu untuk mewujudkan situasi belajar mengajar yang efektif (Siahaan, 2005). Pembelajaran online ini juga mengajarkan kita pendidik dan peserta didik bahwa kita belajar disegala situasi tanpa dibatasi ruang dan waktu. ${ }^{4}$ Study from home membuat para orang tua mengalami kesulitan baik itu pengenalan orang tua terhadap pembelajaran online, atau terkait metode pembelajaran serta tugas tugas yang harus dikumpulkan secara berskala melalui media online. Telah menjadi tugas guru untuk memberikan semangat dan motivasi bagi orang tua dan siswa dalam kondisi seperti ini. Karna motivasi sangat penting sebagai pendorong, pengarah dan sekaligus penggerak prilaku seseorang untuk mencapai suatu tujuan. ${ }^{5}$

Kegiatan belajar mengajar di sekolah merupakan kegiatan terbaik untuk proses pembelajaran, dan banyak bukti ketika di sekolah sangat mempengaruhi produktivitas dan pertumbuhan ekonomi. ${ }^{6}$ Namun, jika dihadapkan dalam kondisi seperti ini, belajar menjadi sangat sulit apalagi untuk usia anak- anak yang masih berada di jenjang bawah. Mereka butuh pengawasan ekstra. Selama kondisi pandemi covid-19 guru hanya bisa

\footnotetext{
${ }^{4}$ Sungkono.Pembelajaran jarak jauh berbasi teknologi informasi.( Majalah ilmiah pembelajaran nomor 1.2005 )

${ }^{5}$ Redakdi MIN Malang 1, Strategi Meningkatkan Motivasi Belajar, (Malang: Copyringt Malang, 2007), hal. 8

${ }^{6}$ Baharin, R., Halal, R., dll, 2020, Impact of Human Resource Investment on Labor Productivity in

Indonesia, Iranian Journal of Management Studies, 13(1), hal. 139-164.
} 
mentrasfer ilmu pengetahuan dan memberikan tugas. Dan guru hanya sebagai fasilitator yang memberikan arahan dan nasehat. Semua kegiatan disekolah dialihkan ke rumah dan secara tidak langsung memaksa para orang tua untuk terlibat dalam proses pembelajaran. Banyak orang tua yang menceritakan pengalamannya selama mendampingi anak anak mereka baik itu positif maupun negatif.

2. Pembelajaran Jarak Jauh (PJJ) atau

Daring pada Masa Pandemi Covid-19

Pembelajaran jarak jauh merupakan proses pendidikan yang terorganisasi yang menjembatani keterpisahan antara guru dan murid dan dimediasi oleh pemanfaatan teknologi dan pertemuan tatap muka yang minimal (M. Budi Jatmiko, 2020). Pembelajaran jarak jauh merupakan sekumpulan metode pengajaran dimana aktivitas pengajaran dilaksanakan secara terpisah dari aktivitas belajar. Pemisah kedua kegiatan tersebut dapat berupa jarak fisik maupun non fisik. ${ }^{7}$ Dengan PJJ ini setiap peserta didik tetap mendapatkan haknya dalam proses belajar. Setiap individu memiliki kesempatan belajar tanpa hambatan apapun (Bates, 1995).

Tujuan pembelajaran jarak jauh adalah memberikan layanan pendidikan pada kelompok masyarakat yang tidak dapat mengikuti pendidikan secara tatap muka atau reguler (UU SIKDIKNAS pasal 31 ayat 2). Kemudian fungsi dari pembelajaran jarak jauh adalah meningkatkan perluasan dan pemerataan akses pendidikan, serta meningkatkan mutu dan relevansi pendidikan (PP 17 pasal 118 ayat 1 ).

Dengan kemajuan teknologi pemanfaatan media seperti komputer, laptop dan handphone, membantu kita semua dalam pembelajaran jarak jauh.

7 Hamzah B.Uno.Model Pembelajaran ( Jakarta: Bumi Askara. 2007).
Jaringan internet yang kita tahu saat ini telah merevolusi dunia menjadi industri 4.0 telah membawa dunia pendidikan lebih maju dan modern. Dengan jaringan internet ini telah menjadikan proses pembelajaran menjadi lebih luas, interaktif dan lebih fleksibel. Internet dapat menjadi media komunikasi dalam proses pembelajaran jarak jauh, sekaligus dapat berperan sebagai sumber pembelajaran. ${ }^{8}$ Tidak bisa dipungkiri bahwa semua pihak yang menjalani pembelajaran jarak jauh akan mengalami kepanikan baik guru maupun siswa. Masalah teknis menjadi salah satu kendala dari sekian banyak kendala dan problem dalam proses pembelajaran jarak jauh. Masalah teknis yang ditemui biasanya mulai dari kendala kuota, signal, hingga kendala dari aplikasi online yang kita pakai.

Secara keseluruhan mungkin kita belum siap untuk melakukan pembelajaran jarak jauh saat ini, apalagi banyak siswa yang mengeluh tentang gagalnya memahami materi yang disampaikan lewat PJJ. Hal ini memang dirasa wajar karena baik siswa dan guru belum adanya peralihan dan kemampuan adaptasi dari proses pembelajaran seperti ini. Terlebih lagi pada dasarnya setiap siswa memiliki kemampuan dan pengalaman yang berbeda dengan siswa lainnya yang mungkin sudah terbiasa dengan pembelajaran online. Setidaknya terdapat tiga faktor yang mempengaruhi kemampuan siswa untuk menyelesaikan pembelajaran daring, yakni faktor eksternal, internal dan kontekstual. Beberapa faktor eksternal diantaranya adalah kendala waktu, dukungan keluarga, lingkungan sekitar dan masalah keuangan. Selain itu juga faktor internal yang

\footnotetext{
${ }^{8}$ Sadiman, arif s. Jaringan sistem Belajar
} jarak jauh Indonesia, Pusat teknologi komunikasi dan informasi pendidikan,( Jakarta : Depdiknas. 1999). 
berkaitan dengan disiplin dan kemampuan mengatur waktu, hal tersebut juga terkait dengan bagaimana siswa harus dapat menyiapkan kedisiplinannya untuk fokus pada pembelajaran daring dengan pengawasan orang tua. Sementara faktor kontekstual lebih cenderung kepada aplikasi online yang tidak ramah kepada pengguna (user-frendly), kemampuan penguasaan teknologi, kurangnya interaktivitas, jaringan yang lemah, dan kendala kuota.Semua kegiatan pembelajaran jarak jauh di lakukan dengan menggunakan berbagai media, seperti vidio, audio, WA/SMS, Google Classrom, Google Meet, Google Form, komputer, laptop, tab, dan ponsel berbasis android ataupun IOS.

3. Evaluasi Pendidikan di Era Covid -19

Evaluasi pendidikan merupakan proses penilaian dengan jalan membandingkan antara tujuan yang diharapkan dengan kemajuan dan prestasi nyata yang dicapai (Lessinger, 1981). Pelaksanaan Penilaian Akhir Tahun (PAT) untuk kenaikan kelas di tengah wabah pandemi Covid-19 harus mengutamakan prinsip fleksibilitas, berkeadilan, nondiskriminatif, dan tak merugikan siswa.

Jika di sekolah pelaksanaan PJJ sudah efektif maka nilai kenaikan kelas bisa diambil dari akumulasi proses pembelajaran selama 1 semester, baik record nilai sebelum pandemi maupun setelah pandemi (PJJ). Menilai adalah tantangan bagi kepala sekolah, pengawas, dan dinas pendidikan yang terkadang tak cukup arif dan bijak dalam proses penilaian siswa di masa pandemi meskipun prinsip pengelolaan sekolah berdasarkan 'Manajemen Berbasis Sekolah' (MBS). Atau ada juga fakta kepala sekolah belum percaya diri sepenuhnya dan otonom dalam mengelola PJJ. Mengingat rumitnya birokrasi pendidikan daerah dan pelaporan administratif yang terkadang tak rasional dan berkeadilan ${ }^{9}$

Ujian Sekolah dapat dilakukan dalam bentuk portofolio nilai rapor dan prestasi yang diperoleh sebelumnya, penugasan, tes daring, dan/atau bentuk asesmen jarak jauh lainnya. Sekolah yang telah melaksanakan Ujian Sekolah dapat menggunakan nilai Ujian Sekolah untuk menentukan kelulusan siswa. Bagi sekolah yang belum melaksanakan Ujian Sekolah berlaku ketentuan :

a. Kelulusan Sekolah Dasar (SD)/sederajat ditentukan berdasarkan nilai lima semester terakhir (kelas 4, kelas 5, dan kelas 6 semester gasal). Nilai semester genap kelas 6 dapat digunakan sebagai tambahan nilai kelulusan.

b. Kelulusan Sekolah Menengah Pertama (SMP)/sederajat dan Sekolah Menengah Atas (SMA) /sederajat ditentukan berdasarkan nilai lima semester terakhir. Nilai semester genap kelas 9 dan kelas 12 dapat digunakan sebagai tambahan nilai kelulusan.

c. Kelulusan Sekolah Menengah Kejuruan (SMK)/sederajat ditentukan berdasarkan nilai rapor, praktik kerja lapangan, portofolio dan nilai praktik selama lima semester terakhir. ${ }^{10}$

Siswa dan guru harus sudah terbiasa dengan perangkat pendukung seperti Google Classrom, Google Meet, Google Form dan Aplikasi Ujian Berbasis Komputer yang bisa di akses secara daring. Beberapa sekolah proses PAT dilakukan menggunakan aplikasi Bimasoft Ujian Berbasis Komputer yang bisa dilakukan secara daring, sedangkan para siswa siswi dapat mengerjakan di rumah dengan

${ }^{9}$ https://www.kompas.com/edu/read/2020/ 05/30/070000871/penilaian-kenaikan-kelas-siswadi-tengah-pandemi-covid-19-jangan-rugikan.

${ }^{10}$ https://www.kemdikbud.go.id/main/blog/ 2020/03/mendikbud-terbitkan-se-tentangpelaksanaan-pendidikan-dalam-masa-daruratcovid19 
perangkat yang dimiliki seperti komputer, laptop, tab, dan ponsel berbasis android ataupun IOS. Para siswa dan siswi juga di dampingi oleh wali kelas dan pengawas, menggunakan google meet untuk memantau siswa dan siswi dalam mengerjakan soal PAT.

Dengan metode pembelajaran digital pada masa kini, evaluasi pendidikan dimasa pandemi covid-19 masih dapat kita lakukan. Seorang guru harus mampu mencari celah dan solusi dalam mengetahui sejauh mana peserta didik mendalami materi yang diajarkan. Meskipun guru hanya sebagai fasilitator, tetap penilaian dan laporan hasil belajar guru yang berhak memberikan hasilnya.

\section{Kesimpulan}

Dari pembahasan di atas dapat kita tarik kesimpulan mengenai digital transformasi evaluasi pendidikan di masa pandemi covid-19:

1. Dengan datangnya pandemi covid-19 sekolah, instansi dan perguruan tinggi menutup semua proses pembelajaran tatap muka dan digantikan menjadi pembelajaran jarak jauh atau daring.

2. Semua kegiatan pembelajaran di lakukan dengan menggunakan berbagai media, seperti vidio, audio, WA/SMS, Google Classrom, Google Mett, Google Form.

3. Ujian Sekolah dapat dilakukan dalam bentuk portofolio nilai rapor dan prestasi yang diperoleh sebelumnya, penugasan, tes daring, dan/atau bentuk asesmen jarak jauh lainnya.

4. PAT dilakukan menggunakan aplikasi Bimasoft Ujian Berbasis Komputer yang bisa dilakukan secara daring, sedangkan para siswa-siswi dapat mengerjakan di rumah dengan perangkat yang dimiliki seperti komputer, laptop, tab, dan ponsel berbasis android ataupun IOS.
5. Evaluasi pendidikan dimasa pandemi covid-19 harus tetap dilakukan. Seorang guru harus menilai dan mengetahui sejauh mana peserta didik mendalami materi yang diajarkan. Meskipun guru hanya sebagai fasilitator, tetap penilaian dan laporan hasil belajar guru yang berhak memberikan hasilnya.

\section{DAFTAR PUSTAKA}

Al-Ghazali, 'ihya' Al-Ghazali" (jakarta :faizan, 1989) diterjemahkan oleh Prof. Tk. H. Ismail yakub MA-SH.

Caroline Hodges Persell, 1979, Educations and Inequality, The Roots and Results of Strattification in America's Schools, United States of America: The Free Press.

Azhar

Arsyad, Media

Pembelajaran (Jakarta: PT. Raja Grafindo Persada, 2008).

Sungkono. Pembelajaran jarak jauh berbasi teknologi informasi.( Majalah ilmiah pembelajaran nomor 1 .2005)

$\begin{array}{cr}\text { Redakdi MIN Malang } & \text { 1, Strategi } \\ \text { Meningkatkan } & \text { Motivasi } \\ \text { Belajar, (Malang: } & \text { Copyringt } \\ \text { Malang, 2007) } & \end{array}$

Baharin, R., Halal, R., dll, 2020, Impact of Human Resource Investment on Labor Productivity in

Indonesia, Iranian Journal of Management Studies, 13(1), hal. 139-164.

Hamzah B. Uno. Model Pembelajaran (Jakarta: Bumi Askara. 2007).

Sadiman, arif s. Jaringan sistem Belajar jarak jauh Indonesia, Pusat teknologi komunikasi dan informasi pendidikan,( Jakarta : Depdiknas. 1999).

https://www.kompas.com/edu/read/2020/0 5/30/070000871/penilaiankenaikan-kelas-siswa-di-tengahpandemi-covid-19-jangan-rugikan. 
Pjj: Digital Transformasi Daring Pada Evaluasi Pendidikan Di Era Pandemi Covid-19

https://www.kemdikbud.go.id/main/blog/2

020/03/mendikbud-terbitkan-se-

tentang-pelaksanaan-pendidikan-

dalam-masa-darurat-covid19 
Pjj: Digital Transformasi Daring Pada Evaluasi Pendidikan Di Era Pandemi Covid-19

Rausyan Fikr. Vol. 17 No. 1 Maret-No.2 September 2021. ISSN. 1979-0074 e-ISSN. 9772580594187 | 96 